удк: 94(477.5):061.2:338.43.02 «18/19»

\title{
Place of rural community associations of the late XIX - early XX century in modern classification systems
}

\section{Silka \\ National University of Food Technologies omedalieva@ukr.net}

Key words: Public association, agricultural society, civil society, peasantry.

\begin{abstract}
Summary. At the beginning of the XX century, within Ukraine, at the rural administrative-territorial level, a consolidated social movement was formed, consisting of mutually non-subordinated but mutually-functioning public associations. The article describes the classification schemes of public associations existing in national and foreign historiography. Each of them has advantages and disadvantages, but at the same time provides an optimal study of the history of statutory public sector. The combination of a number of such classifications helps a modern researcher to determine the role and place of public associations in the social life of Ukrainians. The content of the main typological approaches that were used to create the classifications of public associations of the Russian Empire from imperial times to the present is found. Attention is paid to the classification of V. Hessen, V. Czarnoluskii, 0. Stepansky, T. Korzhikhina, 0. Lyubushkina, A. Tumanova, V. Savchuk, I. Demus and many others. The multi-vector approaches, which are due to the application of various criteria and approaches from the constitutionallegal to the historical ones, is noted. It has been established that in modern historiography, despite the number of studies, objects of which were public associations, there is no single classification. Modern Ukrainian historians offer different types of classification of public associations in the late XIX early XX centuries. As empirical material to fill their systems they pay attention to city public associations. In aggregate, such works are an important factual gathering of only the city sector of the public statute initiative. Instead, in the historiographic space a lacuna was formed regarding to the public statute movement, which acted outside the city - in towns and villages. Based on the work of V. Savchuk, the criteria are proposed on the basis of which rural public associations should take their place in the classification schemes. The first criterion is the separation of rural public associations from a large array of statutory organizations according to the purpose. The second is the fixation of «village» public associations. The third is the generalization of the main types of rural community associations, which is realized as a result of analysis and comparison of the goals and objectives of the Society. The fourth one is the elaboration of rural associations based on the organizational and managerial principle. The importance and necessity of determining the place of rural public associations in the general network of public organizations as an integral part of it is emphasized.
\end{abstract}

Formulation of the problem. Modern reform processes in Ukraine stimulate the activation of civic initiative and the activities of diverse associations. An important role in these transformations is given to the Ukrainian village. Its present and future are inextricably linked and partly dependent on the active functioning of special groups of the population whose members are united on the principles of self-organization. Such entities are public organizations. In this context, it is relevant to study the history of civic organizations in the Ukrainian village at the end of the XIX and early XX centuries. This is important, in view of the experience of Ukrainian public initiatives. The Ukrainian peasantry turned out to be an active subject of history at the end of the XIX and early XX centuries, at this time, the peasants joined to the creation of hundreds of public associations of different directions. Territorial coverage, trends, scales and outcomes of rural organizations are a direct historical example for today's rural social movement.

The activity of the peasant community is a natural marker of public consciousness, a means of self-affirmation and self-realization in the 
socio-cultural space. The decisive approach to understanding the emergence, establishment and development of the Ukrainian rural community initiative is to find out its place in the socio-cultural structure of Ukraine in the late nineteenth and early twentieth centuries. At the same time, the rural social statute movement was also connected with the formation of the foundations of civil society in the Russian Empire, and in particular in Ukrainian provinces. We share a view on the notion of «civil society» by Professor of History at the University of Tulsa (Oklahoma, USA) J. Bradley: «Civil society is a space that exists between the individual and the state; it consists of private institutions, public organizations, the market, the sphere of free expression of ideas and religion» [1]. At the end of the XIX and early XX centuries, along with an increase in organizational social activity, there was a rapid change in the political and economic structures of the country. According to Ukrainian historians and philosophers, an important component of the gradual changes in the peasant socio-cultural environment of Ukraine was, according to the formulation of A. Karasia, the institutions of «peasant civil society», or at least its proto-civic forms» [2, p. 23] or «elements of civil society in the countryside» or «paradigmatic peasant society at the beginning of the $X X$ century» in the terminology of S. Markova $[3 ; 4]$.

Analysis of recent researches and publications. Analysis of the historiography of the problem of determining the place of rural community associations in the late XIX and early XX centuries in modern theoretical developments, in particular, in the classification constructions, has shown that attention to the rural statute initiative cannot be defined as complete and all-inclusive. Among contemporary Ukrainian researchers, V. Savchuk [5], T. Slynko, 0. Kushnirenko [6], L. Loiko [7], V. Kravchuk [8], A. Teslitsky [9] and others are engaged in the classification of public associations.

The purpose of the article. The authors of the article set out to synthesize the most commonly used classification of public associations in Soviet, Russian and Ukrainian historiography.

Presentation of the main material. The concept of «civil society» for a modern Ukrainian country is one of the key. Public sphere became the field within which the opportunity for self-realization of every citizen appeared. Ukraine at the turn of the XIX and early XX centuries in the period in which the emergence of the processes of the formation of urban civil society and paradigmatic peasant society was already under way. One of the signs of such processes was the self-organization of the population within the limits of legal voluntary associations of different orientations. The question of the classification of statutory public initiative within the rural area of Ukraine in the late XIX and early XX centuries in modern Ukrainian historiography practically not developed. The basic reason for such situation is the absence of a single criterion in the Ukrainian historiographic space, which would eliminate the discussion about the presence or absence of signs of the existence of civil society in the Russian Empire, and hence in Ukraine, at the turn of the XIX - XX centuries. We are convinced that the study of the system of rural community organizations is required within the framework of the study of the processes of reforming changes of the second half of the XIX and early XX centuries, as well as the component of the all-Ukrainian tendency of formation of public organizations and movements in Ukraine in the late XIX and early XX centuries.

For the first time, the classification of public associations of the Russian Empire was proposed by V. Hessen - the author of the article «Society». It was published in the encyclopedic manual of publishers Brockhaus and Efron in 1897 [10]. According to it, in the category of «Society - as an association of people for achievement of common goals» the following were singled out: «societies of social law» bodies of local and state self-government; «Official public associations» - in this category the author has attracted a sufficiently wide range of organizations; "Societies promoting spiritual development»; «Societies promoting physical development of the population»; «Relief Society»; «Anthropological societies»; «Astronomical Societies»; «Societies for the study of the Bible»; «Societies of geology and mineralogy»; «Societies of naturalists»; «Medical societies»; "Societies of sobriety»», etc. In our opinion, the value of the proposed material is not the identification of classification marks, but the attempt to create a certain grouping of known public associations.

The next attempt to group societies was made by V. I. Charnoluski [11]. In his systematization, it is difficult to identify a single criterion of division, which he used. Meanwhile, it is important for us to emphasize the attention of those rural public organizations that are the subject of the submitted research. Particular fraternities and associations of the Holy Synod; societies of soberness of the spiritual department, civil societies (circles) of sobriety; charitable societies; fire brigades and druzhiny; agricultural societies, accountable to the Main Department of Land Management and Agriculture. The 
proposed schemes contain a large factual material, which, unfortunately, has no theoretical basis.

Soviet historians investigated social organizations as an element of the political sphere of society, divided them into certain groups, based on the purpose, which was recorded in the «Charter» of the organization. 0. D. Stepansky, recognized and respected specialist in the field of the history of public organizations, systematized all the societies into 4 groups: 1) political, 2) economic, 3) guardianship, public health and education, 4) scientific, literary, artistic $[12 ; 13]$. Each group had its own division according to the relevant criteria. Modern researchers point to existing contradictions in the involvement of a societies in the appropriate group that was observed in the investigator's work at various stages of his activity. Village public organizations in the classifications of 0 . D. Stepansky were not reflected as a historical phenomenon.

T. P. Korzhikhina presented a fully interlocked, from a modern point of view, classification of voluntary public associations in Soviet historiography. Immediately note that it was a question of classification within Soviet societies. Thus, the system of civil societies has the following form: The Communist Party, as the only center, is able to unite the masses, equip them with progressive ideas; trade unions - the most mass organization of workers; Komsomol - mass non-partisan youth organization; co-operation - as the best form of peasant consolidation; voluntary associations and employee unions; civic initiative organization [14, p. 37]. Rural grouping, already traditionally for Soviet science, did not fall into the field of view of the researcher.

Another Soviet historian V. R. Leikin-Svirska [15], studying the Russian intelligentsia, drew attention to certain forms of social self-organization in its environment, proposed its division of associations, the criterion of which was chosen by the professional orientation of the vast majority of actual members of the societies: technical societies; forestry societies; societies of surveyors, agronomic and statistical assistance; medical societies; educational societies; law societies; scientific societies; societies of writers and publishers, artists, actors and musicians. The aforementioned classifications, as well as others, which based on the principle of historicism, have not yet been disseminated among researchers. A few societies simply did not get to the proposed systems, for example, associations of amenities, fire brigades, religious communities, etc.

A brief overview of the main basic classification schemes of civic organizations of pre-Soviet and So- viet historiography showed that they did not have a peasant component. Given the peculiarities of the socio-cultural life of the Ukrainian peasantry, the proposed classifications are not suitable for constructing a spectrum of rural community associations in Ukraine in the late XIX and early XX centuries.

Modern Ukrainian historians offer different types of classifications of public associations in the late XIX and early XX centuries. As empirical material to fill their systems, they mostly focus on city public associations. Taken together, such works are an important factual gathering of knowledge about the urban sector of the public statute initiative. The causes of its appearance, which had political, socio-economic and cultural character, were also determined. Instead, in the historiographic space a lacuna was formed regarding to the public statute movement, which acted outside the city - in towns and villages. In his time, 0 . D. Stepansky, already mentioned, describing the social composition of public associations, pointed out that «outside of these associations» remained the bulk of the population - peasantry, urban lowlands, artisans, small civil servants, and semi-intelligentsia». According to him, «they had rather modest possibilities for organizing mutual assistance, rather weak and unstable» [16, c. 66]. Modern Ukrainian historiography gradually refutes this thesis on the pages of a number of studies, drawing attention to the emergence of a rural statutory initiative.

Among the contemporary Ukrainian researchers, T. Slynko, 0. Kushnirenko, L. Loiko, V. M. Kravchuk and many others are engaged in the issue of voluntary societies, and in particular the issues of classification. There is also multidirectional approach, depending on the applied criteria and approaches - from the constitutional-legal to the historical ones. Thus, today's lawyer A. M. Teslitsky distinguishes the following types of public organizations: 1) by way of education and forms of activity: fronts, associations, unions, foundations; 2 ) under the terms of membership: with a formally fixed and formally non-fixed membership; 3 ) by the number of members: mass and elite; 4 ) by way of formation and degree of coverage of masses: spontaneous and consciously organized; 5) by composition - professional, women's, youth, ethnic, etc.; 6) for the internal structure: centralized, decentralized; 7) on the scale of activity: local, national, international; 8) according to the social and legal status: legal, illegal; 9 ) by way of achieving the goal: reformatory, conservative; 10) for social values for the existence and development of society: progressive, conservative, reactionary $[17$, p. 44]. 
Ukrainian philosopher V. Beletsky, recognizing the «third sector» as the basis of civil society, a decisive stabilizing factor and guarantor of the democratic path of development, distinguishes youth, professional, children's, women's, veteran, religious, elite organizations, clubs, «brain» or think tanks [18].

Among Ukrainian historians, researchers of the public statutory movement in Ukraine in the late $X I X$ and mid-XX centuries, working on the problem of creating a universal classification of public associations, we will allocate the work of V. S. Savchuk [19]. Despite the fact that his sphere of interest revolves around public-scientific societies, we are impressed with the proposed typology procedures that we use to create a classification of public associations of Ukrainian villages. So, based on the scheme of VS Savchuk, it is necessary:

1) Identify an array of public associations to be analyzed.

2) Indicate the criteria by which the separation will be, in our case, rural statutory societies, from the general array of civic organizations. The criterion is fixed in the «Statutes» territorial boundaries (village, volost, town), to which the activities of societies are distributed. Note that this criterion is clearly distinguished.

3) Distribute an array of rural community associations for generic types.

4) To form a hierarchically constructed system of criteria of the second order, which belong directly to the generalized types of public organizations and based on the interaction of general and special in their functioning. This criterion is an analysis of goals and objectives. As evidenced by the elaboration of constituent documents, the network of rural community groups consisted of the following associations: agricultural societies, voluntary fire brigades and societies, charity societies, societies of sobriety, community-building organizations, centers of the Red Cross Society, centers of the Society for Rescue on the Water, societies of artistic orientation and etc.

5) To specify for each hierarchical level the criteria of typology of village societies according to the organizational-management principle. According to this criterion, we distinguish: type 1 - independent communities of local (regional, peripheral) type, which in the majority did not have primary structures (branches, departments, etc.) in other areas; type 2 - rural primary cells (branches, departments) of associations of all-Russian, provincial and district levels. This category includes centers of philanthropic societies of the provincial and district levels that arose with the outbreak of the First World War, as well as branches of the Russian Red Cross Society and the Russian Society for Rescue in the waters.

6) Use typology procedures to gain new knowledge in the study of rural community groups (due to the accumulation of empirical data).

Ukrainian scientist 0 . Boreyko has his own view on the classification of public associations [20]. Based on the criteria for the division of the texts of the "Statutes», the researcher divided all societies into two types - legitimate and illegitimate. In turn, the legitimate ones are divided into: public-law (city societies, zemstvos) and private-law. Last - organizations, funds of which held by a limited number of people. In this category, 0 . Boreiko distinguishes the following species and subspecies:

1. societies that contributed to the development of spiritual life:

- societies whose purpose was to develop the moral and value sphere of the people, mainly or entirely on religious grounds (Orthodox Palestine Society, church fraternities, societies of sobriety, care for prisoners);

- societies whose purpose was to increase the mental and aesthetic levels of development of the people, gain elementary education, popularize certain branches of knowledge and science (commissions for the organization of folk lectures, literacy societies, literary and artistic societies);

2. societies whose purpose was to disseminate applied knowledge among children, youth and adults (societies promoting lower commercial education, photographic society);

3. societies whose activities consisted in spreading knowledge about the benefits of developing the physical culture of the people and in organizing sports competitions for the general public (societies of gymnasts);

4. societies that provided financial assistance (charitable societies, child care societies);

5. regional branches of professional teacher organizations, which contributed to solving the legal, professional, moral and material problems of teaching, as well as the promotion of their profession;

6. scientific ethnographic societies.

Among the representatives of modern political science our attention was attracted by the classification of A. V. Matviychuk [21, p. 55]. The diversity of public associations, the researcher classifies according to the directions of activity:

- public associations that unite people on the principle of common goals and problems;

- public associations of the so-called «club type»; 
- associations of social justice or charity;

- public-political organizations, movements and human rights organizations;

- professional associations and trade unions bringing together hired workers and creative workers, negotiate on their behalf, conclude collective agreements and agreements with the administration of enterprises and the government, fight by lobbying the legislative and financial support of its functioning.

Among modern scholars, we also note the work of I. 0. Demus, which followed the historiographic discourse of the period XIX - early XX centuries from the history of scientific societies that functioned in Ukraine during the imperial period. Despite the fact that the historian's attention was focused on urban scientific public associations, the typology of the above-mentioned societies is of direct interest to us, while I. Demus consciously «refused to create in the work a separate classification of investigated multi-sectoral scientific societies, offering them structuring according to the generally accepted classification according to the branches of knowledge» [22]. Thus, she highlights: societies of universal character, societies of a humanitarian nature, natural sciences societies, scientific and technical societies, medical and agricultural societies.

Another classification, which we define in the modern historiographic space, and the elements of which can be used in the structuring of rural community societies, are the works of N. G. Chaika [23]. Studying the scientific institutions at the agricultural societies of the Right-Bank of Ukraine in the second half of the XIX and early XX centuries, the historian proposed their division according to the following criteria:

- according to the scale of activity - all-Russian, regional, local (provincial, county, rural);

- according to the directions of activity - general action, narrow-band (special);

- according to the prevailing forms of activity scientific-educational, commercial-industrial;

- according to the property composition of the members - syndicates of large commodity producers, small-scale cooperative societies of the land peasantry;

- according to the initiators of creation - at the suggestion of the landlords, intelligentsia, peasants. Peasant associations - on their own initiative, on the initiative of zemstvos.

Since the early 90 's in Russian historiography, the tendency to classify public organizations in narrower (regional) bounds is gradually becoming more popular than the entire territory of the Rus- sian Empire. In the historiographic space there is a classification, which is based on the purpose of the societies' activity [24, p. 245]:

- instrumental civic organizations - the goal of the society goes beyond the organization itself;

- expressive public organizations - the purpose of the society is limited to the organization itself.

The view on such a classification within the two provinces in the early 90 's of the XX century suggested 0 . Y. Soboleva. On the basis of the study of the activities of the legal public organizations of the Kostroma and Yaroslavl provinces in the socio-cultural sphere and in the field of social security, she concludes that in the Russian Empire after the 60 's of the XIX century three groups of these organizations acted - scientific, agricultural societies and charitable organizations. And at the end of the XIX century the researcher records the emergence of a number of new partnerships - mutual aid societies, educational, literary, artistic, musical drama and health [25].

The research worker 0 . Y. Lyubushkina, defending two dissertations on the problems of formation and regional specificity of public associations, offers a conditional classification, defining the criterion of division, also the purpose of the activity of societies: local lore, educational, cultural, charitable, national public organizations, mutual societies, agricultural societies and veterinary societies, Orthodox religious non-governmental organizations and healthcare companies [26, p. 7].

In turn, to some of them, for example, to health associations, the researcher applies an additional internal division:

1 - general medical societies, which set a wide range of tasks and combined several types of activities in their work (scientific, sanitary, medical and preventive, sanitary-educational);

2 - highly specialized medical societies whose activities were focused on a particular field of medicine and aimed at the study and treatment of one particular illness;

3 - branch of all-Russian societies - which fully or partially specialized in solving health care problems (League for the fight against tuberculosis, Russian Red Cross Society).

In our opinion, based on the stated statutory tasks and directions of the Society, the organization of the first two types can be included in the scientific and medical. The third type of society represents a public organization in the definition that we use in our work. It is the most fully implemented principle of the establishment of the organization. 
The classification of public organizations within the territorial boundaries of one province in 2000 was presented by A. M. Dobrynina [27]. Taking as a basis the goal of the activities of the societies, the researcher identified the following groups:

1) societies of rational management (associations of landscaping, hunting societies, fishermen, gardeners);

2) relief societies (charitable, Russian Red Cross Society);

3) healthcare societies (medical, pharmaceutical, etc.);

4) sports societies;

5) societies of moral education (societies of sobriety, Orthodox church fraternities, etc.);

6) intellectual development societies (societies of distribution of education, scientific societies);

7) aesthetic societies (organizations of supporters of musical, dramatic and other kinds of arts);

8) entertaining societies (clubs, horse riding fans' societies, etc.).

Modern researcher A. S. Tumanova [28], studying the peculiarities of the social and political life of the Russian Empire, distinguished the following categories of all-Russian public associations:

1) societies, whose activities were aimed at improving urban life in communal and infrastructure areas;

2) societies of social protection;

3) economic societies;

4) medical societies;

5) societies for the study and popularization of literature and arts;

6) clubs;

7) sports and recreation societies;

7) educational societies;

8) scientific societies;

9) the society whose purpose was to promote the state-patriotic education of youth;

10) charity societies.

Historian A. B. Gularian, relying on the results of the study of the features of public life in the Orlovska province in the late XIX and early XX centuries [29] and combining the principles of sociological functionalism with the principles of historicism, proposes his view on the principles of systematization of public organizations. At the heart of its classification are two criteria: the scope of functional diagnosis and the principles of equipment and the social composition of the organization. According to them, the researcher distinguishes four groups with the corresponding subgroups:

1) public organizations of nature orientation;

2) public organizations of social orientation: class (aristocratic and merchant), professional organizations and unions (professional corporations, trade unions of workers, trade unions of artisans, mutual societies, creative unions), non-indigenous organizations, refugees and settlers, societies for the promotion of economic development (agricultural societies and societies by sectors of the economy), social protection of the population (charities and guardianship, aid societies for the disabled, penitentiary charity, children's and educational charity), charitable organizations of foreigners, national minorities, refugees;

3) political public organizations: local groups of the party of socialist-revolutionaries, organization of anarchists and maximalists, organizations and groups of the RSDRP, groups of the constitutional democratic party, organizations of «The Union of 0ctober 17», the black hundreds;

4) public organizations focused on solving personal (living-existential) problems: assistance in emergencies (rescue from natural elements, rehabilitation of victims of social upheaval, fire brigades and druzhina), sports and health, including societies of sobriety, educational, scientific and local lore studies, organizations aimed at providing recreation, religious non-governmental organizations.

In our view, the proposed classification has two conceptual remarks. First, we share the opinion of most researchers on the essence of a public society as an out-of-date organization; therefore, it is inappropriate to involve state organizations (nobles and merchants) in the system of public organizations of the Russian Empire. Secondly, in our opinion, it is worthwhile separating the public sphere of society from the political one. The purpose of the majority of public organizations is to meet the personal interests of each member of the community, and political parties - the achievement of political power in the state or participation in its achievement. According to 0 . Sobolev, public organizations are predecessors of political ones, they became the primary school of engagement in public and political activity $[30, p .1]$. In addition, other elements of the proposed structure need to be discussed.

The aforementioned researcher of social history, B. M. Mironov, denotes the legal public organizations of imperial Russia the term «voluntary social associations» and suggests their view of their grouping [31]:

1) associations connected with the Church. They were engaged in missionary activities, popularized Orthodox perspectives and religious literature, studied the history of the Church and religious life. 
To them, the researcher attracts religious fraternities, church-historical societies, the Orthodox Palestinian Society, the associations of banner-bearers, adherents of church singing, Orthodox russian women, and others like that;

2) mutual assistance societies and economic associations. The purpose of such associations was to organize assistance to their members of the organization of storage of funds, their increase through trade and financial transactions, obtaining loans, protecting the interests of individual social and professional groups, insurance and property protection, etc. In this group the researcher includes savings and loan cash departments, mutual credit societies, consumer society and mutual fire insurance societies;

3) charitable and guardian societies - about prisons, about the poor, about children; women's charity societies, aid societies for pensioners, seriously ill children, etc.; Society for the Protection of Children, Society for the Protection of Animals, Society for Compassion, Society for the Guardianship of Wounded and Sick, Red Cross Society;

4) Societies in the field of art and culture have united fans of art, music, fine arts, choral singing, literature, etc.;

5) scientific, cultural and educational, regional studies and associations of professional development: associations of naturalists, doctors, adherents of literature, archeology, history and ethnography; physical and mathematical, legal, pedagogical, economic, technical, photographic, agriculture;

6) clubs and associations for the organization of family rest - aristocratic associations, merchant clubs, military assemblies, chess clubs, hunting societies, fishermen, gardeners; sports - yacht clubs, fans of gymnastics, bicycles, equestrian sport;

7) secret political and religious associations. Their membership included citizens whose views were disloyal to the current authorities and the Orthodox Church - communities of Old Believers, Masonic lodges, organizations of the Decembrists.

The views of representatives of contemporary Ukrainian historiography on subjects of public movement are, in some cases, radically different. Public organizations are recognized associations of citizens who acted within the framework of the current legislation. Only recognition of their legality allowed such societies to achieve a certain goal and objectives, to interact with the self-government and state authorities. Activities of savings and loan funds, mutual credit societies and consumer associations are studied within the framework of the cooperative movement. The involvement of clubs and associations for the organization of family rest, which, according to B. M. Mironov, were «closed elite clubs focused on expensive entertainment activities», in our opinion, is unlawful. In fact, the researcher himself admits that «the broad masses of the population, about $95 \%$ - peasants, burghers and artisans, as well as students, cadets, soldiers - were left behind».

Thus, for the first time the question of the necessity of creating a universal classification of public associations of the Russian Empire was violated within the limits of the Soviet historiographical paradigm with unconditional authority regarding the investigation of this problem 0. D. Stepansky. After him, V. R. Leikin-Svirskaya, A. S. Tumanova and others addressed the question of classification in different periods. Recently, in the scientific space, too, there were studies in which again the question of the expediency of discussing the criteria that should be the basis of the universal classification of public organizations. The above material, in our opinion, is evidence of a constant search for researchers, in the direction of improving approaches to creating a universal classification of public organizations of the Russian Empire, and Ukraine in particular.

Along with the existence of the above classifications, which we do not reject, we propose for the discussion of the scientific community additional classifications of civic organizations. Separate components of these classifications already sounded in the historiography issue, but they were not united into a single system. The need to use additional classifications, in our opinion, is associated with two factor. The first is the collapse of the Soviet Union and the departure from the Soviet model of the study of public associations, and the second - the restoration of scientific views on the history of Ukraine as the history of the state, the emergence of national historiographical tendencies. Today we are fixing work that reveals some aspects of such classifications. We propose the criteria on the basis of which rural community organizations should take their place in the classification schemes, and, in the future, be seen as one of the elements and the result of reform processes in the Ukrainian peasant environment, namely: the identification of rural community organizations from a large array of rural statutory associations in accordance with the purpose, fixing the actual «rural» non-governmental organizations, generalizing the main types of rural community organizations and detailing rural public organizations by organizational and management principle. 
Conclusions. Consequently, in Ukrainian and Russian historiography, despite the rather broad representation of researches, objects of which were public associations, including rural ones, there is no single classification for them. The issue of its development is controversial. The lack of classification is primarily due to the lack of clear criteria and parameters, which could clearly distinguish between well-known statutory associations. Modern historians suggest different classifications of public associations at the end of the XIX and early XX centuries, but relying on the history, experience and results of the activities of urban public organiza- tions. We are convinced that the facts of existence and relatively long activity of statutory public rural associations were one of the manifestations of the formation of paradigmatic peasant society. Village voluntary statutory organizations are considered by us as an example and result of active changes in the public and social spheres of peasant life, as well as a component of the system of non-profit and non-political rural associations of Ukraine. An important component of their study should be the emergence of a general classification, which will find its place as urban and rural associations.

\section{Sources and Literature}

1. Бредли Д. Общественные организации и развитие гражданского общества в России / Д. Бредли // 0бщественные науки и современность. - 1994. - № 5. - С. 77-89.

2. Карась А. Громадянське суспільство і Україна: пошук дискурсивного контексту свободи й автентичності / А. Карась // Збірник наукових праць (третій випуск), підготовлений за дослідницькою програмою кафедри філософії «Громадянське суспільство як здійснення свободи». - Львів, 2006. - С. 5-33

3. Маркова С. В. Українське парагромадянське селянське суспільство на початку XX ст.: самоврядні інституції) / С. В. Маркова // Вісник Кам'янець-Подільського національного університету ім. Івана Огієнка. Історичні науки. - Кам'янець-Подільський, 2016. - Вип. 9. - С. 312-322.

4. Маркова С. В. Парагромадянське селянське суспільство на початку XX ст. в Україні: аграрно-політичний дискурс / С. В. Маркова // Гуржіївські історичні читання. - Черкаси, 2015. - Вип. 10. - С. 60-62.

5. Савчук В. Громадсько-наукові об'єднання: процедури типологізації / В. Савчук // Ейдос. - Київ, 2009. - Вип. 4. - C. 153-164.

6. Слинько Т. М. Конституційно-правовий статус об'єднань громадян в Україні / Т. М. Слинько, 0. Кушніренко. - Харків : Арсіс, 1998. - 176 с.

7. Лойко Л. Типологічне позиціювання національних організацій в індустріальній структурі громадянського суспільства / Л. Лойко // Політичний менеджмент. - Київ, 2005. - № 5. - С. 51-60.

8. Кравчук В. М. Громадські організації і держава: взаємовідносини в умовах формування громадянського суспільства в Україні (теоретико-правові аспекти) / В. М. Кравчук. - Тернопіль : ТзОВ «Терно-граф», 2011. - 260 с.

9. Тесліцький А. М. Класифікація громадських об'єднань в Україні / А. М. Тесліцький // Науковий вісник Чернівецького університету. - Чернівці, 2011. - Вип. 559. Правознавство. - С. 44-47.

10. Гессен В. Общество / В. Гессен. - Режим доступу: http://www.vehi.net/brokgauz/

11. Справочная книжка об обществах и союзах / сост. В. И. Чарнолуский. - СПб. : Тип. Б. В. Вольфа, 1912. - 158 c.

12. Степанский А. Д. История общественных организаций дореволюционной России / А. Д. Степанский. - Москва : МГИАИ, 1979. - 81 с.

13. Степанский А. Д. Общественные организации России на рубеже XIX-XX веков / А. Д. Степанский. - Москва : МГИАИ, 1982. - 91 с.

14. Коржихина Т. П. 0 комплектовании государственных архивов СССР материалами общественных организаций / Т. П. Коржихина // Советские архивы. - 1973. - № 4. - С. 36-41.

15. Лейкина-Свирская В. Р. Русская интеллигенция в 1900-1917 гг. / В. Р. Лейкина-Свирская. - Москва : Мысль, 1981. -285 c.

16. Степанский А. Общественные организации в России / А. Степанский // Открытая политика. - 1995. - № 5 (7). - С. 65-68.

17. Тесліцький А. М. Класифікація громадських об'єднань в Україні / А. М. Тесліцький // Науковий вісник Чернівецького університету. - Чернівці, 2011. - Вип. 559. Правознавство. - С. 44-47.

18. Білецький В. С. «Третій сектор» як основа громадянського суспільства / В. С. Білецький // Збірник наукових праць (третій випуск), підготовлений за дослідницькою програмою кафедри філософії «Громадянське суспільство як здійснення свободи». - Львів, 2006. - С. 62-83.

19. Савчук В. Громадсько-наукові об'єднання: процедури типологізації / В. Савчук // Ейдос. - Київ, 2009. Вип. 4. - С. 153-164.

20. Борейко 0. М. Просвітницько-педагогічна діяльність громадських товариств Волині (друга половина XIX початок XX ст.) / 0. М. Борейко. - Житомир : Вид-во Житомир. держ. ун-т ім. I. Франка, 2011. - 184 с.

21. Матвійчук А. В. Громадські організації як чинник становлення громадянського суспільства : дис. ... канд. політ. наук : 23.00.02 / А. В. Матвійчук. - Київ, 2008. - 184 С. 
22. Демуз I. 0. Наукові товариства України XIX - початку XX ст.: полілог учених і епох: монографія / I. 0. Демуз. - Переяслав-Хмельницький: ФОП Лукашевич 0. М., 2014. - 681 с.

23. Чайка Н. Г. Становлення та розвиток наукових установ при сільськогосподарських товариствах Правобережної України (друга половина XIX - початок XX ст.) : автореф. дис. ... канд. іст. наук : 07.00.07 / Н. Г. Чайка. - Київ, 2005. - 22 с.

24. Общество // Современная западная социология. Словарь. - М., 1991. - С. 245.

25. Соболева 0. Ю. Региональные легальные общественные организации на рубеже XIX-XX вB. (1890-1914 гг.) (на материалах Костромской и Ярославской губернии) : автореф. дис. ... канд. ист. наук : 07.00.02 / 0. Ю. Соболева. - Иваново, 1993. - 19 с.

26. Любушкина Е. Ю. Общественные организации Ставропольской губернии и Кубанской области в период с 1860-х гг. по октябрь 1917 г. : дис. ... канд. ист. наук : 07.00 .02 / Е. Ю. Любушкина. - Ставрополь, $2004 .-428$ с.

27. Добрынина А. М. Неполитические общественные организации Владимирской губернии в 1860-х - феврале 1917 гг. : автореф. дис. ... канд. ист. наук : 07.00 .02 / А. М. Добрынина. - Иваново, 2000. - 29 с.

28. Туманова А. С. Общественные организации как модель самоорганизации российского общества в начале XX века. Типология добровольных обществ, их влияние на социально-культурную среду и самосознание населения / A. С. Туманова // Самоорганизация российской общественности в последней трети XVIII - начале XX вв. - Москва, 2011. - С. 217-264.

29. Гуларян А. Б. Проблема классификации общественных организаций в дореволюционной России / А. Б. Гуларян // История и современность. - 2013. - № 3. - С. 153-158.

30. Соболева 0. Ю. Региональные легальные общественные организации на рубеже XIX-XX вв. (1890-1914 гг.) (на материалах Костромской и Ярославской губернии) : автореф. дис. ... канд. ист. наук : 07.00 .02 / 0. Ю. Соболева. - Иваново, 1993. - 19 с.

31. Миронов Б. М. Добровольные ассоциации и гражданское общество в позднеимперской России / Б. М. Миронов // Журнал социологии и социальной антропологии. - 2008. - Т. XI, № 1. - С. 183-195. 